\title{
Translator's Subjectivity in Feminist Translations-A Case Study of Eileen Chang's Translation Practice
}

\author{
Zhihai Chen, Xiaoxiu Zhang \\ Changchun Institute of Technology, Changchun, Jilin, 130012
}

Keywords: translator's subjectivity; feminist translation theory; female thoughts; Eileen Chang.

\begin{abstract}
Eileen Chang is a great feminist writer. Compared with her writing works, her translations, which are the important part of her literary contributions, are ignored to some extent. In point of this, by analyzing Eileen Chang's purposeful choice of the original text and translation strategies, the paper tries to explore the display of translators' subjectivity from the perspective of feminist translation. This paper shows that feminist translators' subjectivity are manifested greatly on the translation practice of Eileen Chang. The significance is that this research presents a new perspective to study the translators' subjectivity. Meanwhile, the study of Eileen Chang's translation practice p directions and experience for the feminist translators.
\end{abstract}

\section{Introduction}

Feminism could be revealed from the practice of translators' purposeful selection of original text and the choice of women-favored translation strategies. Translators can choose the proper source text so as to highlight the female identity. Just to say, sometimes, feminist translators will question all linguistic and non-linguistic signs in the text, including the diction, grammar, concepts and ideas. And then they resort to creative translation to foreground the gender bias in the source text in order to promote readers' reflection on gender issues (Xu, 2004). In the foll rovides owing part, how Eileen Chang's translation practice enhances the status of translator and manifests her subjectivity will be analyzed in detail.

\section{Introduction to Eileen Chang's feminist thought}

In the 1930s, Eileen Chang studied at St. Marys Women's School in shanghai. She was influenced deeply by her mother and her aunt, who were all modern women with new thought, which is the source of her feminist thought. She showed her concern for women when she was young. In her My Great Expectations, she said:

"They shall ask him to help in reading their future goals, to be a writer, musician, an educationalist, or an ideal wife" (Chen, 2004:58).

As mentioned above, Eileen Chang is proud of being a woman. She believes that women are not inferior to men and they can do as well in many fields as men. In her mind, to be an ideal wife is not the only thing to do, instead, it is the last choice for women. She also said:

"Yes, St. Mary’s Hall may not have the largest dormitories and the best-looking school gardens among all the schools in China, but she certainly possesses the finest and the hardest working girls, who shall glorify her with their brilliant future" (Chen, 2004:58).

Apparently, Eileen Chang is always in pride when talking about women. The above adjectives largely reflect her concern and respect for women.

And most of Eileen Chang's works describe about women's misfortune to reveal the reality of women's being derogatory. She aims at breaking the dominating position of men. For example, in The Golden Cangue, the women are in power, but not the men. 


\section{Translator's subjectivity in Eileen Chang's choice of texts}

Although Eileen Chang has never publicly claimed that she is a radical feminist writer, her feminist tendencies can be seen in the details in her literary works and translations. On one hand, she chooses to translate her own works, fully conveying the feminist ideas, highlighting the female consciousness. On the other hand, she would like to challenge the male authors' works, building up the female identity in the translated version in order to break the situation of patriarchy.

\subsection{The selection of The Old Man and the Sea}

Many readers know, The Old Man and the Sea is a male author's work which describes the man fights with bitterness of life so as to change his fate. The theme of the novel praises the calm bravery of men, but nothing about women. Eileen Chang's choice of this work to translate to manifest female translators' subjectivity takes great challenge and has its profound significance.

Generally, many female translators tend to choose female authors' works, however, Eileen Chang chooses to translate a male work and shows her unique appreciation of The Old Man and the Sea. By translating it, she wants to arouse those women, who are treated unfair under the male-dominated society, to learn about the strong willpower from the protagonist, to struggle for their legal rights and to fight for their dignity.

\subsection{The selection of her own work}

Popovich, editor of the dictionary of translation studies, first time to define the term "self-translation". "Self-translation is a translation of the original text into another language by the author himself," he said. In self--translations, the author and translator is involved in the process of writing and translating. This way of translating well displays translator's subjectivity.

Actually, Eileen Chang once declined others to translate her works. She sticks to self-translation her own works. For the self-translators, it is no doubt that self-translation is the best way to execute "Writing Project". It is why Eileen Chang chooses to translate her own work The Golden Cangue

(《金锁记》) . It is possible for her to profoundly display her female identity and to intensify the female idea in the original text. Of course, another reason for Eileen Chang to translate her own works is that the themes of most of her works are about women and the novels reflect Eileen Chang's concern for women.

\section{Subjectivity in women-favored translation strategies}

Feminist translators point out, language is not only for communication, but also a way of manipulation. Therefore, in order to imprint their subjectivity, they usually intervene the text to manifest female identity. Similarly, Eileen Chang shows her subjectivity in translations by using some women--favored translation strategies, namely, supplementing, prefacing footnoting and hi-jacking.

\subsection{Supplementing in The Golden Cangue}

Supplementing which compensates for the differences between language calls for interventionist moves by the translator (Simon, 1996:14). The technique of supplementing is employed by many translators, what is different is that feminist translators focus more on compensating gender expressions. In Eileen Chang's translation, the strategy is adopted to handle the expressions which show women's identity, as well as by applying the technique to profoundly reveal the oppression on women in old society.

Example 1: “这两句话, 说响不响, 说轻也不轻。人从里的新娘子平板的脸与胸震了一震 多半是龙凤烛的火光的跳动。”(《金锁记》, 张爱玲, 1967)

"Her last remark could not be called loud, nor was it exactly softly. Could the bride, surrounded by a crowd as she was, possibly have registered a quiver on her severely flat face and chest? Probably it was just a reflection of the flames leaping on the tall pair of dragon-and phoenix candles." (The Golden Cangue, Eileen Chang, 1967)

When translating, Eileen Chang adds the adverb "severely" and the adjective "flat" and "tall". The high dragon candle symbolizes the traditional customs and powerful feudal forces (Yang, 2007:82). 
The severely flat face and chest of the bride suggest that women were extremely oppressed in the old China. The translation is handled in this way so that the contrast is more intense. In addition, Eileen Chang expresses her contempt and resentment against the feudal men who oppressed women.

Example 2: “七巧道: “我稀罕你？等我有了钱了，我不愁你不来，只愁打发你不开。” 嘴里虽然硬着, 鳌不住那鸣咽的声音, 憋了一上午的满腔幽恨, 借着这因由尽情发泄了出来。” (《金锁记》,张爱玲, 1967 )

“'What do I care?' Cao Qiqiao said. 'When I have money, I won't have to worry about you not coming, only how to get rid of you.' Despite her harsh words she could not hold back the sobs that got louder and louder. This quarrel had made it possible for her to release the frustrations pent up all morning long."

(The Golden Cangue, Eileen Chang, 1967)

In this part, Eileen Chang's supplementation "got louder and louder" exactly presents the excitement feeling of the heroine. The purpose of the supplement is to arouse women to strive for their equal rights and to fight for their status in the male--dominated society. Woolf argues, women must reject the social construct that women are in dominated position and establish in their identities.

By supplementing, Eileen Chang's feminist thought of revolting against the patriarchal society is clearly showed to readers.

\subsection{Prefacing in the version of The Old Man and the Sea}

Barbara Godard remarked, “...important instruments of active engagement with the source and participation in the creation of meaning” (Hatim, 2001:135). Prefaces are usually adopted by feminist translators to explain the intentions of the source text, and outline the strategies they use in their translation, in order that the reader of the translation can have a full idea of their translation process (Simon, 1996).

Eileen Chang regards the technique of the preface as an ideal space to express her special feelings for the original works, meanwhile, displaying her feminist identity with an implicit way. And she also expresses her attitude that hoping the female readers to draw the encouragement from her version.

In the preface, she points out, "Many sentences in this novel are full of the bitterness of life although they seem prosaic. I don't know whether young friends understand it or not. It is because I like it so much so I am afraid that my translation cannot express the profound humor and sorrow of the original novel and also the charming rhythm of the language” ( Chen, 2004 ).

For Eileen Chang, apparently, preface is a proper battlefield to claim her attitude toward her work of translation and to manifest her female identity. In the preface to The Old Man and the Sea, she also says: "The old man in this novel displayed amazing willpower when fighting with the sea that is not the superman’s, but a kind of spirit belonged to whole human” ( Chen, 2004: 191 ).

The word "superman" is applied by Eileen Chang in her essay "Speaking of Women", and she is grouchy with using that word and disappointed about the male-dominated society. Here Eileen Chang deliberately emphasizes that the willpower is not the superman's, but that spirit should belong to both women and men. She praises the contribution of women in long history.

Therefore, in her preface, Eileen Chang expresses her thought: to translate this novel is not only for men, and the old man's willpower should belong to women and men; she wants to praise not only men but also women.

Through the above analysis, it can be seen that as an excellent feminist translator, Eileen Chang gives her own understanding of the novel in the preface and she hopes especially female readers to get aware of and learn about the strong willpower from the old man, and it is really the best weapon for Eileen Chang to manifest her subjectivity and to show her identity.

\subsection{Hijacking in the version of The Old Man and the Sea}

Hi-jacking which means "the appropriation of a text whose intentions are not necessarily feminist by the feminist translator" (Simon, 1996:15). Feminist translators think they have the right to "manipulate" the politically incorrect text, they have to "correct" the words and sentences which contain hostile meaning to women in the source text. For example, when translating Govan's book, "letter from someone else”, Harwood translated Quebecois into Quebecois-e-s to make the word including all female residents in theory. Eileen Chang uses this technique in her translations as well. 
She translates male author's work The Old Man and the Sea by the way of hi-jacking. Her version, for sure, is dissimilar with the two male translators Hai Guan and Wu Lao. In the following analysis, it will be vividly displayed.

Example 3: “And pain does not matter to a man.” (The Old Man and the Sea, Ernest Miller Hemingway, 1952)

“痛苦在一个男子汉不算一回事。”（《老人与海》，海观，1963）

“疼痛对一条汉子来说，算不上什么。”(《老人与海》，吴劳，1995）

“疼痛是不碍事的, 并不伤人。（《老人与海》, Eileen Chang, 1979)

According to Oxford Advanced Learner's English-Chinese Dictionary (fourth edition), “man” has the meaning of “男子汉” and “人”. In the above examples, the two male translators all translate “man” into“男子汉”or“汉子”, which shows that both of them highlight the hero’s perseverance. But, Eileen Chang translates it into“人”that covers the meaning of men and women. When translating, Eileen Chang weakens the word, which men are pushed forward. She wants to break the control of man-directed, which is of course her way to display women's status.

In Eileen Chang's view, the quality of "manly" does not only belong to men, women also have the spirit. Because no matter how difficult life is, women are able to live with calm (Eileen Chang, 1995:188). It is similar with the strong willpower of the old man in The Old Man and the Sea.

Example 4: ... and all the time the male had stayed with her, crossing the line and circling with her

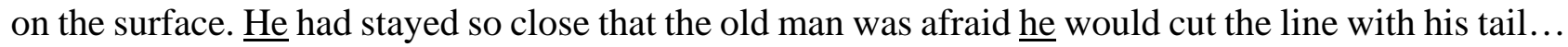
(The Old Man and the Sea, Ernest Miller Hemingway, 1952)

……那条雄鱼始终待在它身边，在吊索下窝来窝去，陪着它在水面上一起打转。这雄鱼 离吊索好近, 老人生怕它会用它的尾巴把吊索割断, ...... (《老人与海》, 吴劳, 1995)

……那雄的一直和她在一起, 它在钓丝上面游过去, 陪着她一同在水面上转圈子。它离她 那样近, 老人很怕它会用尾巴将钓丝斩断, ...... ( 《老人与海》, Eileen Chang, 1979)

In the translated text, Eileen Chang does not translate “he” into “他”but translate “she” into“她”. Why did she do so? After "hi-jacking" the word "he", the feeling of Eileen Chang's respect and loving for women seems like stronger. Creating the female images in the target text can make the female consciousness merge together with the source text. It is a technique to promote the status of the female translators.

By analyzing Eileen Chang's version The Old Man and the Sea, it can be easily found that Eileen Chang's feminist thought is showed clearly. Although The Old Man and the Sea is a novel that is full of male consciousness, Eileen Chang employs women-favored translation strategies to establish the women images and to manifest her subjectivity. Eileen Chang handles the sentences that contain differences in the culture and language between the original text and the target text with a technique of preface and supplement in a gentle way.

The paper views, compared with the translated text of the two male translators, the version of The Old Man and the Sea of Eileen Chang is more fascinating for the old man in her version is more lifelike.

\section{Limitations of Translator's Subjectivity in Feminist Translation}

Doubtlessly, feminist translation theory has widened the scope of translation studies. It is a breakthrough for the field of translation studies. The theory has successfully deconstructed the authority of original texts and the domination of men and has led to people's rethink on the criteria of traditional translation theory and translator's subjectivity as well. However, to realize its political purpose, it puts too much emphasis on the feminist translator' manipulation of language and intervention, which to some extent departs from or even distorts the nature of translation activity. Inevitably the theory has encountered scathing critique from all sides.

First, critics from outside favor an 'objective' approach to scholarship and writing and they think that "gender issues are too emotional, too ideological, in fact, too subjectivity for real scholarship" (Flotow, 1997:77) .One type of criticism centers on the issue of "gender neutrality" Eugene Nida 
questions it in response to feminist initiative in Bible translation. He thinks that most living creatures are of either female or male sex, so "there are no cognitive models to form a basis for understanding such gender neutrality" (Flotow, 1997:78). As to the feminist activity-language reform, Nida argues that inclusive language in Bible translation is "no valid solution to the issue of gender neutrality". For example, the term "androgyny" can be taken as a form of gender neutrality, referring to the union of the physical characteristics of both sexes in one being. However, "andro" which denotes the male part of the word still comes first.

\section{Conclusion}

In a word, the limitations of the feminist translation lie in its overemphasis on the translator's subjectivity and creative role in translation. If the female translator's subjectivity is projected to the extreme, the danger of another kind of discourse power tendency will arise.

\section{References}

[1] Bassnett, Susan \& Levefere. A Translation, History and Culture [C]. London: Pinter, 1990.

[2] Chamberlain, Lori. Gender and the Metaphoric of Translation [A]. Lawrence Venuti (Ed.). Rethinking translation: Discourse, Subjectivity, Ideology [C]. London and New York: Routledge, 1992.

[3] Eileen Chang. Written on water. New York: Columbia University Press, 2004.

[4] Eileen Chang. Golden Cangue in Twentieth-century Chinese stories, New York: Columbia University Press, 1971.

[5] Flotow, Luise Von. Translation and Gender: Translating in the 'Era of Feminism'[M]. Manchester: St Jerome Publishing, 1997. 